Boise State University

ScholarWorks

World Languages Faculty Publications and

Presentations

Department of World Languages

2019

History, Humanity, and the Literary Construction of Haiti in Evelyne Trouillot's Works

Jason Herbeck

Boise State University

This document was originally published in Palimpsest: A Journal on Women, Gender, and the Black International by SUNY Press. Copyright restrictions may apply. doi: 10.1353/pal.2019.0000 


\title{
History, Humanity, and the Literary Construction of Haiti in Évelyne Trouillot's Works
}

\author{
Jason Herbeck \\ Boise State University
}

Évelyne Trouillot’s novels, short stories, poetry, children's stories, and play—not to mention her interviews, op. ed. pieces, and academic articles - introduce us to chapters of Haiti's history spanning roughly two hundred and fifty years. From a plantation in the former French colony of Saint-Domingue during the 1750s to present-day, postearthquake Haiti, the experiences, trials, and tragically haunting memories of her characters serve to bring into focus countless rifts in the country's complex and often conflicted past. Despite the turbulent time periods in which we discover these protagonists, and the resulting adversity to which they are prone, their struggles are not waged on battlefields; nor do they lead to conspicuous positions of power befitting heroines or, alternately, to the imprisonment or execution of would-be martyrs. For as quintessential as the Vodou ceremony of the Bois Caïman, the decisive Battle of Vertières, or the notorious Fort Dimanche are to understanding Haiti's past, Trouillot's characters have not (yet, at least) appeared at the forefront of these or other similarly iconic places and events in the country's history. Instead, they emerge in what might be considered the chambres interdites of Haiti's past—places that have remained closed, hidden, or merely overlooked within and by the country’s dominant historical narratives.

Akin to the eponymous "forbidden room" in the author's first published collection of short stories, the far corner of which, concealed by curtains, "invaded [the young narrator's] dreams, covering them with a clammy fear which flowed over [her], redolent and warm,"1 the settings of Trouillot's works provide opportunity for confronting what has been described as the institutionalized silencing of history. ${ }^{2}$ In effectively opening the door to elusive recesses of the country's past, her narratives are recounted on a human scale - not that of nations and institutions-that as a result challenges the traditionally hegemonic, authoritarian discourses of and about Haiti and its people. Whether it be with respect to the colonial French empire, the influential policies of the United States (including embargos, both occupations and the temporary protected status designation), the political and economic grip of private international businesses and NGOs, the decisions and actions of Haitian leaders, or the so-called "discourses of disaster"3 involving Haiti, the trepidations, hardships, and determination of Trouillot's protagonists constitute subtle yet consistent counternarratives of suffering, struggle, and survival. "We need memories to build ourselves [ . . into] stronger human beings," Trouillot has affirmed, adding: "Fiction can help us endure our fears."”

As a means of imagining under-represented groups whose voices have been all but lost in the folds of history, Trouillot divulges their perspectives and stories in the most unexpected of spaces: under a flapping blue tarp tied over the back of a pickup truck transporting clandestine passengers to the Haitian-Dominican border (Le Bleu de l'île); in a backyard under the night sky, on a roughly hewn star-gazing platform (Le Mirador aux étoiles); in a newly refurbished gingerbread house, as seen through the reluctant eyes of a thirteen-year-old boy whose parents have decided to leave Boston and return to Haiti to live in the centuries-old structure that has been in their family for generations ("Ma Maison en dentelle de bois"); in the seemingly secure confines of a four-wheel drive Honda weaving through the crowded streets of Port-au-Prince (Le Rond-point); in the muted room of a bedridden woman living in a Parisian nursing home (La Mémoire aux abois).

As unanticipated or out of the ordinary as the settings of Trouillot's stories might be, her works do not privilege a unique perspective or narrative. Instead, alternating focalizations or narrations consistently frustrate claims of consensus and frames of reference. In "Le Détour," when a woman takes a wrong turn and finds herself in a rundown area of the nation's capital, far off the beaten path of her comfortable lifestyle, her anxiety is just as soon countered by the bitter indignation of a man who, down on his luck, notices she doesn't belong there: "What was that woman doing here? Her luxurious appearance was like a slap in the face to his destitute condition and, with an instinctive hostility, he gazed scornfully at this vehicle that was too nice, too new despite the layers of mud splashed upon it since daybreak." 5 Similarly, it is unnervingly difficult to take a side upon learning the contrasting accounts of the Duvalier era as recalled, respectively, by the former dictator's aging widow and a young hospice nurse in La Mémoire aux abois. Even when there is a common bond of affection between characters, as in Absences sans frontières, determining what to prioritize when in their relationship sets a father and daughter apart both figuratively and literally. And whereas 
This is an author-produced, peer-reviewed version of this article. The final, definitive version of this document can be found online at Palimpsest: A Journal on Women, Gender and the Black International, published by SUNY - State University of New York. Copyright restrictions may apply. doi: 10.1353/pal.2019.0000

the unbridled enthusiasm of the narrator's son in “Je m'appelle Fridhomme” is near infectious when he invites his seventy-year-old father to come live with him and his family in Boston, the latter's sober memories and disposition render his deferred response not only predictable but entirely intelligible.

Situating her characters in different eras of Haiti’s turbulent chronology, Trouillot proposes that we take full stock of those who are caught up—and risk being swept away—in the march of history: "All things considered, the silences to be broken are those which envelop the nameless about whom we don't speak and whose lives erode around us." 6 Consequently, while events and time periods such as preindependence Saint-Domingue, the American Occupation, Duvalierism, the presidency of Jean-Bertrand Aristide, 9/11, and the 2010 earthquake all factor as backdrops in Trouillot's texts, it is personal, intimate, day-to-day struggles to which she devotes her-and thus calls our-attention. She notes in this respect, "I believe that literature renders society alive and real. [...] [I]ndividuals who are part of the Haiti I live in [include] men, women and children who want to live happily like the rest of humanity, who are neither monsters nor victims." ${ }^{7}$ Confronting circumstances seemingly beyond their control, Trouillot's characters not only find themselves veering sharply from their desired course but moreover into the path of others whose own trajectories have been similarly diverted against their will. The tense but ultimately crucial contact between strangers that results takes center stage, as well as the social, ideological, and economic gaps that increasingly divide them.

The very first thought attributed to François Duvalier's moribund yet ever-calculating widow in La Mémoire aux abois asserts, "Silence is ultimately the surest means of control." ${ }^{8}$ By chronicling new voices and imagining difficult dialogues, Trouillot continually undermines the traditionally hegemonic control of Haiti's historical narrative. Much like the stubbornly optimistic protagonist of L'œil-Totem who refuses to be uprooted from her home because she hopes to unearth the legendary jar of gold coins buried somewhere on her property, Trouillot returns fervently, time and again, to the history of Haiti as a means of exposing the redeeming value of its too-often neglected humanity. In each of her works, history is unsettled as she reveals individuals' obstacles, yearnings, and triumphs, and, in so doing, encourages her readers to do as she does- to challenge memories. ${ }^{9}$ In the postface of Rosalie l'infâme, she notes in hindsight, "I wasn't intending to write a historical novel. May I be forgiven, then, for the few discrepancies and creative liberties I've taken. I only seek to acknowledge my characters' humanity." ${ }^{\prime 10}$ Curiously, what Trouillot appears to underscore in discussing her intentions for the novel and the eventual outcome is the tacit correlation between the fundamentally human qualities of her characters and the historical nature of the text. Indeed, whereas it is undoubtedly beneficial to have a good knowledge of Haiti's history when reading Trouillot's works in order to comprehend the broader contexts and conflicts to which they refer, her writings just as soon reveal the grave shortcomings of the country's narrative. As a unique space of construct, Trouillot's literary works not only shed much-needed light-both new and critical — on the legitimacy of the nation's historical record, but give voice to precisely the types of individuals, experiences, and perspectives that are so sorely missing from it.

\section{Notes}

1. Évelyne Trouillot, La Chambre interdite: nouvelles (Paris: L’Harmattan, 1996), 145, translation mine.

2. Michel-Rolph Trouillot, Silencing the Past: Power and the Production of History (Beacon Press, 2015).

3. Deborah Jenson, "The Writing of Disaster in Haiti: Signifying Cataclysm from Slave Revolution to Earthquake," in Haiti Rising: Haitian History, Culture and the Earthquake of 2010, ed. by Martin Munro (United Kingdom: Liverpool University Press, 2010), 102-11.

4. Trouillot, "Challenging Memories to Rewrite History" (keynote talk at the First Boise State University Department of World Languages International Conference on Cultural Studies, Boise State University, Boise, ID, March 16, 2018).+

5. Trouillot, "Le Détour," in Je m’appelle Fridhomme (Delmas: C3 Éditions, 2017): 30, translation mine.

6. Annette Joseph-Gabriel, “'Tant de silence à briser’: Entretien avec ÉvelyneTrouillot,” Nouvelles Études Francophones 32, no. 1 (2017): 86-87, translation mine.

7. Joseph-Gabriel, “Tant de silence à briser’: Entretien avec ÉvelyneTrouillot,” Nouvelles Études Francophones 32, no. 1 (2017): 85, translation mine.

8. Trouillot, Memory at Bay, trans. Paul Curtis Daw (Charlottesville: University of Virginia Press, 2015), 5.

9. I borrow this phrase from the title of Trouillot's keynote lecture, "Challenging Memories to Rewrite History."

10. Trouillot, The Infamous Rosalie, trans. Marjorie Salvodon (University of Nebraska Press, 2013), 132. 